\title{
Angiotensin Induction of PAI-1 Expression in Endothelial Cells Is Mediated by the Hexapeptide Angiotensin IV
}

David M. Kerins, Qin Hao, and Douglas E. Vaughan

Cardiovascular Divisions, Vanderbilt University Medical Center, and Nashville Veterans Administration Medical Center, Nashville, Tennessee 37232

\begin{abstract}
Recent studies from this laboratory have demonstrated that angiotensin II (Ang II) stimulates the expression of plasminogen activator inhibitor 1 (PAI-1) in cultured endothelial cells. This response does not appear to be mediated via an interaction with either the $A T_{1}$ or the $A T_{2}$ receptor subtype. Since a novel angiotensin receptor has been identified in a variety of tissues that specifically binds the hexapeptide Ang IV (Ang II, [3-8]), we therefore examined the effects of Ang IV on the expression of PAI-1 mRNA in bovine aortic endothelial cells. Ang IV stimulated dose- and time-dependent increases in the expression of PAI-1 mRNA. The effect of Ang IV (10 nM) was not inhibited by Dup $753(1.0 \mu M)$, a highly specific antagonist of the $\mathrm{AT}_{1}$ receptor, or by PD123177 (1.0 $\mu \mathrm{M})$, a highly specific antagonist of the $\mathrm{AT}_{2}$ receptor. In contrast, the $\mathrm{AT}_{4}$ receptor antagonist, WSU1291 (1.0 $\mu \mathrm{M})$, effectively prevented PAI-1 expression. Although larger forms of angiotensin (i.e., Ang I, Ang II, and Ang III) are capable of inducing PAI-1 expression, this property is lost in the presence of converting enzyme or aminopeptidase inhibitors. These results indicate that the hexapeptide Ang IV is the form of angiotensin that stimulates endothelial expression of PAI-1. This effect appears to be mediated via the stimulation of an endothelial receptor that is specific for Ang IV. (J. Clin. Invest. 1995. 96:25152520.) Key words: plasminogen activator inhibitor 1 - fibrinolysis $\bullet$ angiotensin $\bullet$ endothelium $\bullet$ vascular $\cdot$ renin-angiotensin system
\end{abstract}

\section{Introduction}

The fibrinolytic system serves as one of the major endogenous defense mechanisms against intravascular thrombosis. Endothelial cells play a critical role in the regulation of intravascular fibrinolytic activity, serving as a major source of tissue-type plasminogen activator and its inhibitor, plasminogen activator

Address correspondence to Douglas E. Vaughan, M.D., Cardiology Division, Vanderbilt University Medical Center, Room 352B MRB2, Nashville, TN 37232. Phone: 615-322-2318; FAX: 615-936-1872; Email: Doug.vaughan@mcmail.vanderbilt.edu

Received for publication 24 April 1995 and accepted in revised form 27 July 1995.

The Journal of Clinical Investigation, Inc.

Volume 96, November 1995, 2515-2520 inhibitor-1 (PAI-1) ${ }^{1}$ in blood. PAI-1 is a member of the serine protease inhibitor (serpin) family and was initially identified in the medium of cultured bovine aortic endothelial cells (BAEC) (1). Endothelial cell production of PAI-1 is regulated by a number of factors including TGF- $\beta$, lipopolysaccharide and TNF $\alpha(2)$, and thrombin $(3,4)$.

Before PAI-1 was discovered, it was recognized that the prolonged infusion of angiotensin (Ang) II could precipitate myocardial infarction in animals (5). The mechanism of this effect has not been characterized, but presumably involves a combination of vasoconstriction and prothrombotic effects (6). A role for Ang II in the regulation of fibrinolytic balance was first recognized by Olson et al. (7) who described the induction of PAI-1 production by Ang II in cultivated murine astrocytes. This observation has been followed by studies demonstrating that infusion of Ang II to healthy volunteers results in a dosedependent increase in plasma PAI-1 concentrations (8). Furthermore, pharmacological interruption of Ang II production by an angiotensin converting enzyme inhibitor (ACEI) in patients with uncomplicated myocardial infarction is associated with a reduction in PAI-1 activity (9). Recent studies have confirmed this relationship with Ang II inducing PAI-1 expression in vascular smooth muscle cells (10) and in cultured endothelial cells (11).

Importantly, the induction of PAI-1 expression in BAEC endothelial cells is not prevented by the administration of specific antagonists of either the type 1 or type 2 angiotensin receptor $\left(\mathrm{AT}_{1}\right.$ or $\mathrm{AT}_{2}$, respectively). These results suggest that this response is mediated by a pharmacologically distinct form of the angiotensin receptor. In addition to the $\mathrm{AT}_{1}$ and $\mathrm{AT}_{2}$ receptors, evidence is accumulating supporting the existence of an angiotensin receptor that binds to a smaller fragment of angiotensin, the hexapeptide 3-8 fragment (Ang IV) of Ang II. Ang IV is generated by the sequential cleavage of two amino acid residues from the amino terminus of Ang II by aminopeptidases localized to the endothelial surface. Binding sites for Ang IV have been recognized in guinea pig brain $(12,13)$, mouse neuroblastoma (14), bovine adrenal cortical cells, and coronary endothelium $(15,16)$.

These experiments were designed to characterize further the response of endothelial cells to angiotensin and to address the hypothesis that these responses are mediated by an endothelial receptor that is specific for Ang IV.

1. Abbreviations used in this paper: ACEI, angiotensin converting enzyme inhibitor; Ang, angiotensin; BAEC, bovine aortic endothelial cells; PAI-1, plasminogen activator inhibitor 1 . 


\section{Methods}

Materials. Fetal bovine serum and bovine calf serum were obtained from Hyclone Laboratories (Logan, UT). Tissue culture medium was from GIBCO BRL (Gaithersburg, MD). Endothelial mitogen and Dilacetylated LDL were obtained from Integrated Biotechnology (Stroughton, MA). Amastatin, bestatin, gelatin, penicillin, streptomycin, antibody against von Willebrand factor, and trypsin/EDTA were from Sigma Chemical Co. (St. Louis, MO). Ang I, Ang II, Ang III, and Ang IV were from Bachem California (Torrance, CA). Dup 753 was kindly provided by Ronald D. Smith (Du Pont Pharmaceutical Co., Wilmington, DE) and PD123177 was from John Kababian (Parke Davis Pharmaceutical Co., Ann Arbor, MI). WSU1291, [ $\mathrm{Val}^{1} \Psi\left(\mathrm{CH}_{2}-\right.$ $\mathrm{NH})^{1-2}$ ] AngIV, a partial nonpeptide antagonist of the Ang IV receptor (17), was kindly provided by J. W. Harding (Washington State University, Pullman, WA). [ ${ }^{32}$ P]dUTP was from New England Nuclear (Boston, MA)

Cell culture. BAEC were obtained from fresh bovine aortas (18) and harvested using $0.1 \%$ collagenase as described previously (11). Cells of passage 1 were exclusively used in these experiments. BAEC were grown to confluence in 100 -mm tissue culture dishes, washed twice with sterile PBS, and then incubated overnight in serum-free DME containing $1.0 \mu \mathrm{M}$ captopril to minimize autocrine angiotensin effects. The cells were washed with fresh serum-free DME (in the absence of captopril) and exposed to Ang I, Ang II, or Ang IV in the presence or absence of the $\mathrm{AT}_{1}$ receptor antagonist Dup $753(1.0 \mu \mathrm{M})$, a highly specific antagonist of the $\mathrm{AT}_{2}$ receptor, PD123177 $(1.0 \mu \mathrm{M})$, or the $\mathrm{AT}_{4}$ receptor antagonist, WSU1291 $(1.0 \mu \mathrm{M})$, for $6 \mathrm{~h}$.

RNA isolation and measurement. Total cellular RNA was prepared from confluent cultures of BAEC by the acid guanidium thiocyanatemethod (19) followed by isopropanol precipitation (RNAzol; Cinna Biotecx, Houston, TX). RNA pellets were resuspended in DEPC-treated $\mathrm{H}_{2} \mathrm{O}$ and their concentrations were determined by absorbance at 260 $\mathrm{nm}$. The relative amounts of specific mRNA present were quantified by Northern hybridization using specific riboprobes. RNA $(18 \mu \mathrm{g})$ was size fractionated on $1.2 \%$ formamide agarose gels and transferred to nylon membranes (Zeta probe ${ }^{\circledR}$; Bio-Rad Laboratories, Richmond, CA) and crosslinking was performed under ultraviolet light, with exposure to $254 \mathrm{~nm}$ for $30 \mathrm{~s}$ at $1.5 \mathrm{~J} / \mathrm{cm}^{2}$ (Bio-Rad Laboratories). The membranes were prehybridized overnight at $60^{\circ} \mathrm{C}$ in a mixture of $50 \%$ formamide/ $5 \times \mathrm{SSC} / 5 \times$ Denhardt's solution, $1 \%$ SDS containing sonicated, heatdenatured, salmon sperm DNA (200 $\mu \mathrm{g} / \mathrm{ml})$. Membranes were hybrid-

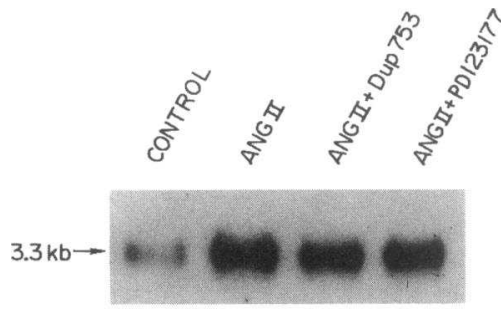

Figure 1. Effect of Ang II on PAI-1 expression by cultured endothelial cells. Confluent cultures of BAEC were washed and then incubated in serum-free DME in the presence of captopril ( 1 $\mu \mathrm{M})$ overnight. The cells were then washed and incubated in the presence of vehicle or Ang II ( 10 $\mathrm{nM})$, for $6 \mathrm{~h}$, in the absence and presence of the $\mathrm{AT}_{1}$ receptor antagonist Dup $753(1 \mu \mathrm{M})$, and the $\mathrm{AT}_{2}$ receptor antagonist PD123177 $(1 \mu \mathrm{M})$. The expression of the 3.3-kb PAI-1 mRNA is demonstrated in the upper panel. To control for variations in gel loading, the relative amounts of RNA in each lane were visualized by staining with ethidium bromide and photographed.

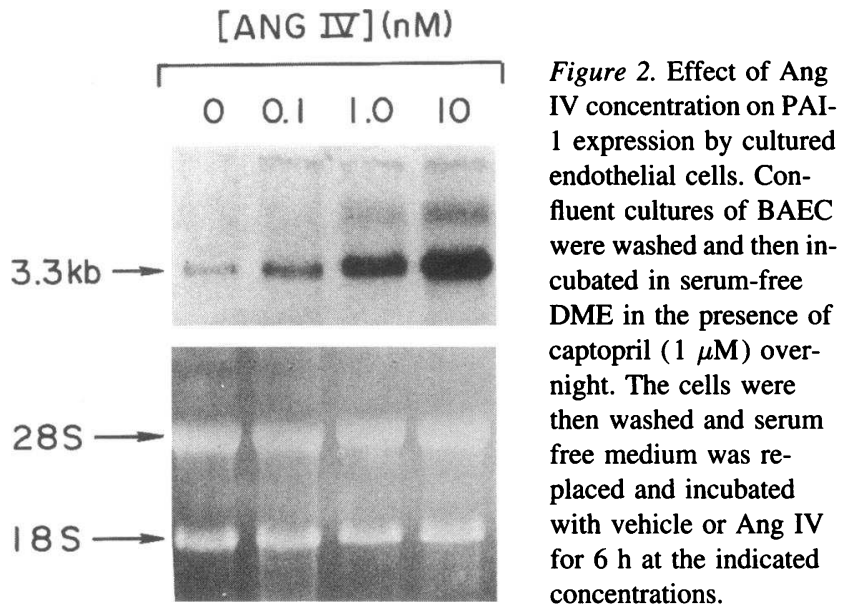

ized overnight with PAI-1 riboprobes labeled with $\left[{ }^{32} \mathrm{P}\right] \mathrm{dUTP}$ at $60^{\circ} \mathrm{C}$ in a shaking water bath, washed using $0.2 \times \mathrm{SSC}$ and $0.1 \% \mathrm{SDS}$, initially at room temperature for $30 \mathrm{~min} \times 2$, then at $68^{\circ} \mathrm{C}$ in $0.1 \times \mathrm{SSC}$, $0.1 \%$ SDS for $30 \mathrm{~min}$, air dried, and exposed to Kodak XAR film with intensifying screens at $-70^{\circ} \mathrm{C}$. Relative RNA loading was determined by examination of ethidium-stained gels. Reflectance densitometry of the ethidium-stained $28 \mathrm{~S}$ bands was used for normalizing autoradiographic data.

cDNA riboprobes. The cDNA template for this probe consisted of a 600-bp fragment containing nucleotides 389-994 of PAI-1 and was kindly provided by Dr. Paul Declerck (University of Leuven, Belgium). Complementary 0.6-kb mRNA transcripts to PAI-1 were generated using a commercially available kit (Maxiscript ${ }^{\text {; }}$; Ambion Inc., Austin, TX). The T7 phage RNA polymerase was used for the in vitro synthesis of RNA transcripts from the DNA template.

\section{Results}

Effect of Ang II on PAI-1 mRNA expression. After pretreatment with captopril $(10 \mu \mathrm{M})$, BAEC were exposed to Ang II (10 $\mathrm{nM}$ ) for $6 \mathrm{~h}$ in the absence and presence of specific antagonists of the $\mathrm{AT}_{1}$ and $\mathrm{AT}_{2}$ receptor subtypes (Dup $753[1 \mu \mathrm{M}]$ and PD123177 $[1 \mu \mathrm{M}]$, respectively). At the end of the exposure period the cells were washed and solubilized and total RNA was extracted as described. Fig. 1 demonstrates the results of Northern blot analysis using a riboprobe to PAI-1. In control cells, PAI-1 mRNA was expressed at low, but detectable, levels. Exposure of the cells to Ang II resulted in a $3.2 \pm 1.7$-fold (mean \pm SEM) increase in the expression of PAI-1 message ( $n$ $=5)$. In comparison with cells treated with Ang II alone, the expression of PAI-1 mRNA was $89.6 \pm 17.6 \%(n=4)$ in the presence of a 100 -fold excess of Dup 753, and $111 \%(n=2)$ in the presence of a 100-fold excess of PD123177.

Effect of Ang IV on PAI-1 mRNA expression. In these experiments confluent cultures of BAEC were exposed to Ang IV over the concentration range of $0-10 \mathrm{nM}$ (Fig. 2). Ang IV resulted in a dose-dependent increase in the expression of PAI1. Compared with vehicle-treated controls, Ang IV (10 nM) induced on average a 5.3 \pm 2.6 -fold increase in PAI- 1 mRNA levels $(n=4)$. A time-dependent effect of Ang IV on PAI-1 expression was also demonstrated (Fig. $3 \mathrm{~A}$ ). The induction of PAI-1 mRNA expression produced by Ang II is evident within $1 \mathrm{~h}$ and is maximal at $4 \mathrm{~h}$ (Fig. $3 \mathrm{~B}$ ).

Effect of amastatin on the response to Ang II and Ang 

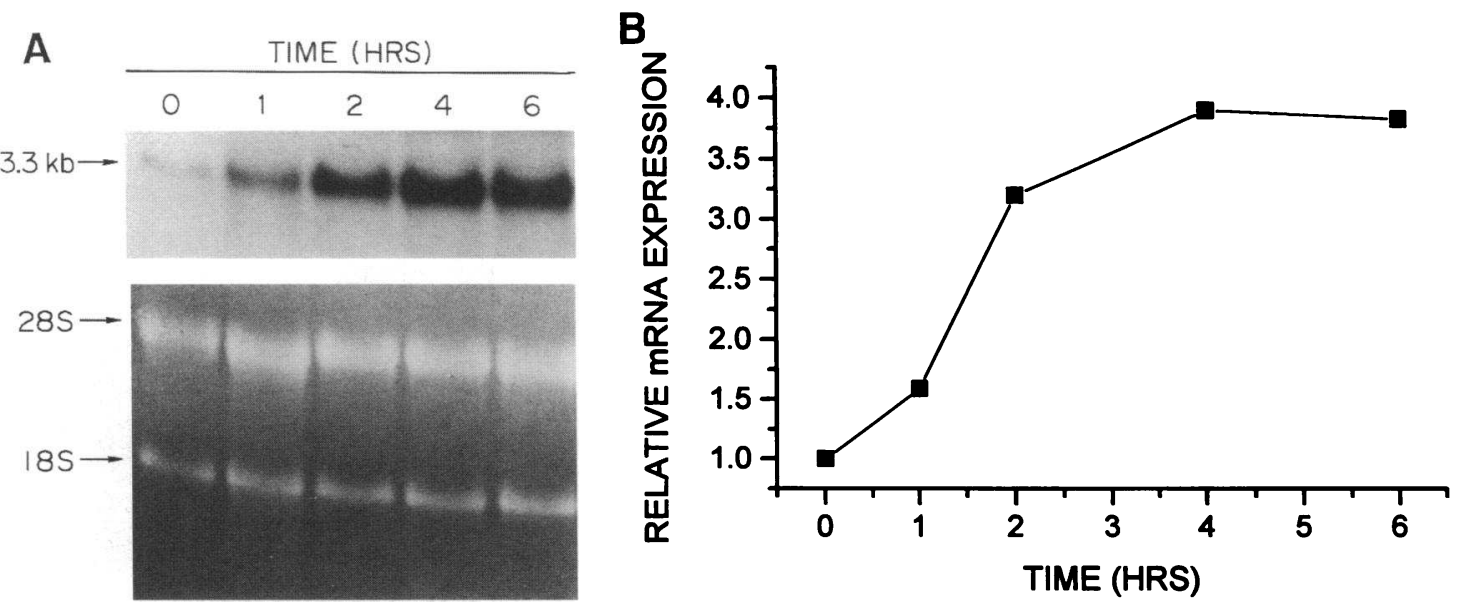

Figure 3. (A) Effect of duration of Ang IV on PAI-1 expression by cultured endothelial cells. Confluent cultures of BAEC were washed and then incubated in serum-free DME in the presence of captopril $(1 \mu \mathrm{M})$ overnight. The cells were then washed and incubated with vehicle or Ang IV for 1-6 h. (B) Time course of ANG IV induced increase of PAI-1 expression by BAEC. Expression of PAI-1 mRNA after exposure to ANG IV was determined by densitometry and normalized using the $28 \mathrm{~S}$ band.

IV. Amastatin is a potent inhibitor of endopeptidases (20) and prevents the conversion of Ang II to smaller fragments including Ang IV. To investigate the role these aminopeptidases play in regulating the induction of PAI-1 mRNA levels by Ang II, cells were exposed to Ang II ( $10 \mathrm{nM})$ in the presence of increasing concentrations of amastatin $(0-1,000 \mathrm{nM})$. As demonstrated in Fig. $4 A$, amastatin resulted in a dose-dependent reduction in the expression of PAI-1 mRNA. In contrast, amastatin did not alter the expression of PAI-1 after exposure of the cells to Ang IV (10 nM, Fig. $4 \mathrm{~B}$ ). In the presence of amastatin (1 $\mu \mathrm{M})$, the PAI- 1 mRNA signal was $80 \%$ of that seen in untreated control cells. In contrast, the PAI-1 mRNA expression in cells treated with Ang IV and amastatin $(1 \mu \mathrm{M})$ was 3.6-fold greater than controls.
Competitive inhibition of Ang II induction of PAI-1 expression. The compound WSU1291 is a potent partial nonpeptide inhibitor of $\mathrm{AT}_{4}$ binding (17). The relative potencies of specific antagonists of the $\mathrm{AT}_{1}, \mathrm{AT}_{2}$, and $\mathrm{AT}_{4}$ receptor subtypes (Dup 753, PD123177, and WSU1291, respectively) on the endothelial cell response to Ang IV are illustrated in Fig. 5. The $\mathrm{AT}_{1}$ and $\mathrm{AT}_{2}$ receptor antagonists were less effective than WSU1291 (1 $\mu \mathrm{M})$ in preventing the Ang IV (10 $\mathrm{nM})$ stimulated increase in PAI-1 mRNA levels. PD123177 $(1 \mu \mathrm{M})$ resulted in a $6 \pm 5 \%$ $(n=3)$ reduction in the response to Ang IV, Dup $753(1 \mu \mathrm{M})$ was associated with a $16 \pm 8 \%(n=4)$ increase in the expression of PAI-1 mRNA.

Identification of Ang IV as the requisite peptide for PAI1 expression. The renin-angiotensin system is comprised of a

A
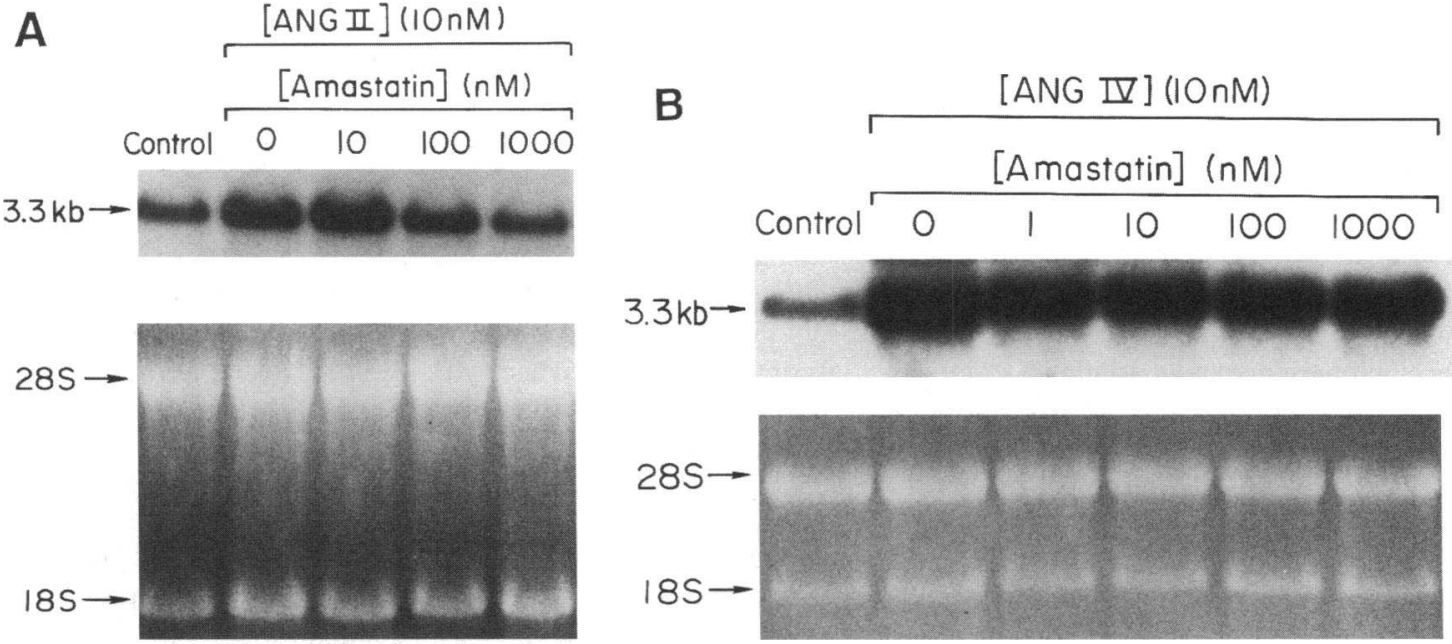

Figure 4. (A) Effect of the aminopeptidase inhibitor amastatin on the effect of Ang II on PAI-1 expression by BAEC. Confluent cultures of BAEC were washed and then incubated in serum-free DME in the presence of captopril $(1 \mu \mathrm{M})$ overnight. The cells were then washed and incubated with vehicle or Ang II $(10 \mathrm{nM})$ in the absence and presence of increasing concentrations of amastatin. $(B)$ Effect of the aminopeptidase inhibitor amastatin on the effect of Ang IV on PAI-1 expression by BAEC. Confluent cultures of BAEC were washed and then incubated in serum-free DME in the presence of captopril $(1 \mu \mathrm{M})$ overnight. The cells were then washed and incubated with vehicle or Ang IV (10 nM) in the absence and presence of increasing concentrations of amastatin. 

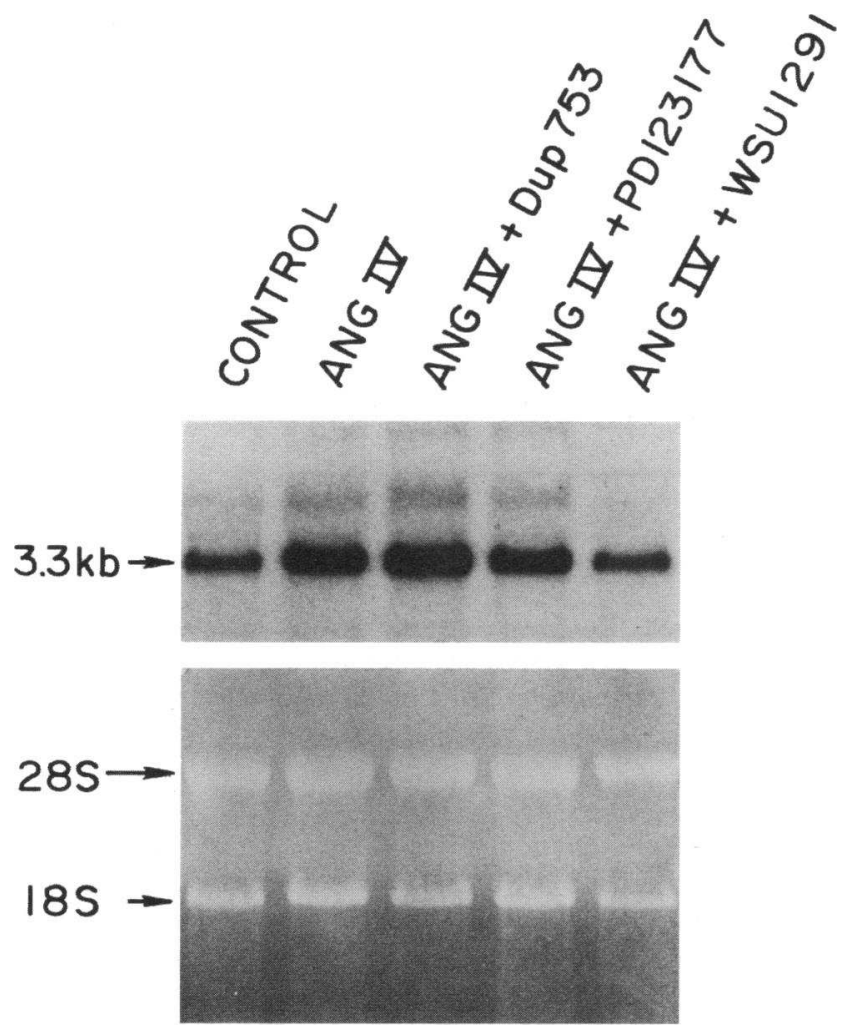

Figure 5. Effect of angiotensin receptor antagonists on the effect of Ang IV on PAI-1 expression by cultured endothelial cells. Confluent cultures of BAEC were washed and then incubated in serum-free DME in the presence of captopril $(1 \mu \mathrm{M})$ overnight. The cells were then washed and incubated with vehicle or Ang IV (10 nM) in the presence of the $\mathrm{AT}_{1}$ receptor antagonist Dup $753(1 \mu \mathrm{M})$, the $\mathrm{AT}_{2}$ receptor antagonist PD123177 $(1 \mu \mathrm{M})$, or the $\mathrm{AT}_{4}$ receptor antagonist WSU1291 $(1 \mu \mathrm{M})$.

sequence of reactions that results in the formation of peptide fragments of angiotensin which differ in their composition of functional precursors. In this experiment, a series of angiotensin peptides was examined for its ability to induce PAI-1 expression in the presence or absence of selective peptidase inhibitors, as demonstrated in Fig. 6. Captopril $(10 \mu \mathrm{M})$, which prevents the conversion of Ang I to Ang II, also blocked the induction of PAI-1 expression. Administration of Ang II (10 nM) resulted in the expected increase of PAI-1 expression but this effect was blunted by amastatin $(1 \mu \mathrm{M})$. A similar response to Ang III $(10 \mathrm{nM})$ in the absence and presence of amastatin $(1 \mu \mathrm{M})$ was obtained. Finally, it is again demonstrated that the hexapeptide Ang IV is sufficient to stimulate the expression of PAI-1. As demonstrated in Fig. $4 \mathrm{~B}$, amastatin had no effect on the response of endothelial cells to Ang IV.

\section{Discussion}

These experiments demonstrate that Ang IV induces an increase in the expression of PAI-1 in cultured BAEC. This response exhibits both a time and a dose dependence and it appears that angiotensin is not capable of inducing endothelial PAI-1 mRNA expression until it is converted to the hexapeptide Ang IV. These results provide an extension of our prior observations
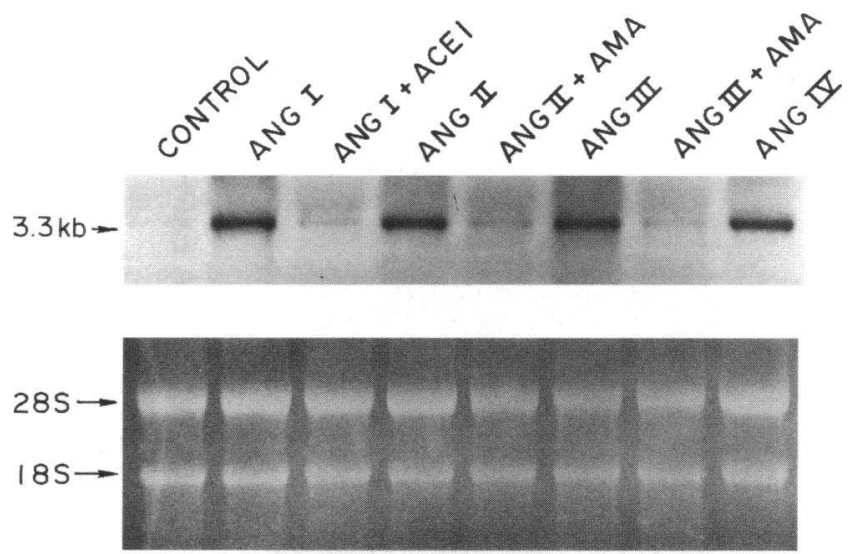

Figure 6. Effect of inhibitors of the conversion of angiotensin on the effect of angiotensin on PAI-1 expression by cultured endothelial cells. Confluent cultures of BAEC were washed and then incubated in serumfree DME in the presence of captopril ( $1 \mu \mathrm{M})$ overnight. The cells were then washed and incubated with vehicle or with Ang I ( $10 \mathrm{nM})$ in the absence or presence of captopril ( $1 \mu \mathrm{M})$, Ang II ( $10 \mathrm{nM})$ in the absence or presence of amastatin $(1 \mu \mathrm{M})$, Ang III $(10 \mathrm{nM})$ in the absence or presence of amastatin $(1 \mu \mathrm{M})$, or Ang IV (10 nM).

demonstrating the interaction of angiotensin with endothelial cells and suggest that this interaction occurs via the $\mathrm{AT}_{4}$ receptor. This is the first demonstration that the expression of PAI1 in response to angiotensin exposure is specifically due to Ang IV.

Binding sites for a novel angiotensin receptor that is specific for Ang IV have been demonstrated in a variety of tissues including rabbit brain (21), smooth muscle cells (22), and mammalian heart membranes (23). In addition, binding sites on endothelial cells have been demonstrated for Ang IV (15). Functional consequences of the binding of Ang IV include dilatation of rabbit brain arterioles (21) and exploratory locomotor activity in rats $(24)$.

In this study, we present data demonstrating that the hexapeptide Ang IV is fully capable of inducing endothelial PAI-1 expression. Furthermore, this effect can be blocked by a specific $\mathrm{AT}_{4}$ receptor antagonist (WSU1291). Importantly, this effect of the $\mathrm{AT}_{4}$ receptor antagonist appears to be specific and not due to undefined general effects on cellular function, since endothelial cells retain their morphologic characteristics and proliferative capacity when cultured in the presence of WSU1291 (data not shown). All of the experimental data presented in this manuscript were obtained using BAEC that had been subcultured only once. Although later passage cells have been examined for their responses to Ang II and Ang IV, the results have been less consistent. The reasons for this are unclear but may represent a functional manifestation of cellular transformation.

Although prior studies from this laboratory have demonstrated that Ang II stimulates the expression of PAI-1, the specific pharmacological subtype of angiotensin receptor mediating this response was not defined (11). The current studies again demonstrate that angiotensin is capable of stimulating the expression of PAI-1. There were differences in the basal expression of PAI-1 expression from experiment to experiment; however, an increase in PAI-1 expression in response to Ang II was consistently detected (Figs. 1, $4 \mathrm{~A}$, and 6). 
The experiments combining angiotensin converting enzyme inhibition and Ang I demonstrate that although Ang I is capable of stimulating this response, this likely occurs via the conversion of Ang I to smaller fragments. A deductive analysis of fragments of Ang I also demonstrated that the response to Ang II is likely dependent upon its conversion to smaller fragments, as demonstrated by the requirement of aminopeptidase activity. In contrast, Ang IV is the smallest fragment of angiotensin that is capable of inducing this response. At present no smaller physiologically active forms of angiotensin have been demonstrated; however, the possibility that even smaller fragments are involved cannot be excluded. However, the experiments combining Ang IV and amastatin demonstrate that an aminopeptidase-dependent cleavage of Ang IV to an active fragment is not necessary for this effect. Furthermore, in our own studies, the pentapeptide fragment of Ang II (4-8) does not induce PAI-1 expression (data not shown).

These experiments confirm an important role for endothelial aminopeptidases in the conversion of Ang II to physiologically active fragments such as Ang III and Ang IV. At least two separate aminopeptidases are involved in this process, aminopeptidase $A$ (angiotensinase $A$ ) cleaves the aspartic acid residue at position 1 to convert Ang II to Ang III, while aminopeptidase $M$ removes the arginine residue, resulting in the hexapeptide Ang IV. Amastatin is a potent inhibitor of both these enzymes, and has an $\mathrm{IC}_{50}$ for aminopeptidase $\mathrm{M}$ of $0.2 \mu \mathrm{M}$ (25). The current studies suggest that the endothelial cell functions autonomously in the conversion of Ang I to Ang IV and confirm a physiologically relevant role for the aminopeptidases. They also support a potentially important role for an aminopeptidase inhibitor in modulating the angiotensin-dependent effects on PAI1 expression. The response of a structurally distinct aminopeptidase inhibitor, bestatin, has been assessed recently using porcine aortic endothelial cells. Bestatin $(1 \mu \mathrm{M})$ results in a similar blunting in the response to Ang II, while this inhibitor does not appear to diminish the response to Ang IV (data not shown).

These results may have important clinical implications. Administration of ACEIs to patients with left ventricular dysfunction is associated with a reduction in the frequency of ischemic events (26-28). More recently, Wright et al. (9) demonstrated that the administration of captopril to survivors of uncomplicated myocardial infarctions was associated with a reduction in PAI-1 activity (9). Conversely, infusion of angiotensin results in an acute increase in plasma PAI-1 concentrations (8). Thus, alterations in the renin-angiotensin system result in alterations in PAI-1, a risk factor for myocardial infarction (29). In contrast to the beneficial effects of an ACEI on PAI-1 levels, therapeutic administration of specific receptor antagonists to either the $\mathrm{AT}_{1}$ or $\mathrm{AT}_{2}$ receptor subtype would not be expected to reduce endothelial expression of PAI-1 and thus may lack this potentially favorable interaction with the fibrinolytic system. Furthermore, $\mathrm{AT}_{1}$ receptor blockers are associated with increased plasma levels of plasma renin activity and Ang II (30, 31 ), which may lead to increased Ang IV production. This latter effect, if confirmed, could have a deleterious effect on fibrinolytic balance and may inadvertently increase the risk of thrombosis. This later possibility deserves careful scrutiny.

\section{Acknowledgments}

The authors are indebted to J. W. Harding, T. Inagami, and A. J. Naftilan for their helpful discussions.
This research was supported by National Institutes of Health grant HL-51387 (D. E. Vaughan) and by a Merit Review Award from the Department of Veterans Affairs Research Service (D. E. Vaughan). D. E. Vaughan is the recipient of a Clinical Investigator Award from the Department of Veterans Affairs Research Service. D. M. Kerins is the recipient of a New Investigator Award from the Tennessee Affiliate of the American Heart Association.

\section{References}

1. van Mourik, J. A., D. A. Lawrence, and D. J. Loskutoff. 1984. Purification of an inhibitor of plasminogen activator (antiactivator) synthesized by endothelial cells. J. Biol. Chem. 259:14914-14921.

2. Sawdey, M., T. J. Podor, and D. J. Loskutoff. 1989. Regulation of type 1 plasminogen activator inhibitor gene expression in cultured bovine aortic endothelial cells: induction by transforming growth factor- $\beta$, lipopolysaccharide and tumor necrosis factor. J. Biol. Chem. 264:10396-10401.

3. Gelehrter, T. D., and R. Sznycer-Laszuk. 1986. Thrombin induction of plasminogen activator-inhibitor in cultured human endothelial cells. J. Clin. Invest. $77: 165-169$.

4. Dichek, D., and T. Quertermous. 1989. Thrombin regulation of mRNA levels of tissue plasminogen activator and plasminogen activator inhibitor-1 in cultured human umbilical vein endothelial cells. Blood. 74:222-228.

5. Gavras, H., J. J. Brown, A. F. Lever, R. F. MacAdam, and J. I. S. Robertson 1971. Acute renal failure, tubular necrosis and myocardial infarction induced in the rabbit by intravenous angiotensin II. Lancet. 2:19-22.

6. Gavras, H. 1994. Angiotensin-converting enzyme inhibition and the heart. Hypertension (Dallas). 23:813-818.

7. Olson, J. A., K. T. Shiverick, S. Ogilvie, W. C. Buhi, and M. K. Raizada 1991. Angiotensin II induces secretion of plasminogen activator inhibitor 1 and a tissue metalloprotease inhibitor-related protein from rat brain astrocytes. Proc. Natl. Acad. Sci. USA. 88:1928-1932.

8. Ridker, P. M., C. L. Gaboury, P. R. Conlin, E. W. Seely, G. H. Williams, and D. E. Vaughan. 1993. Stimulation of plasminogen activator inhibitor (PAI1 ) in vivo by infusion of angiotensin II. Circulation. 87:1969-1973.

9. Wright, R. A., A. D. Flapan, K. G. M. M. Alberti, C. A. Ludlam, and K. A A. Fox. 1994. Effects of captopril therapy on endogenous fibrinolysis in men with recent, uncomplicated myocardial infarction. J. Am. Coll. Cardiol. 24:67-73.

10. van Leeuwen, R. T., A. Kol, F. Andreotti, C. Kluft, A. Maseri, and G. Sperti. 1994. Angiotensin II increases plasminogen activator inhibitor type 1 and tissue-type plasminogen activator messenger RNA in cultured rat aortic smooth muscle cells. Circulation. 90:362-368.

11. Vaughan, D. E., S. A. Lazos, and K. Tong. 1995. Angiotensin II regulates mediates the expression of plasminogen activator inhibitor-1 in cultured endothelial cells. A potential link between the renin-angiotensin system and thrombosis. J. Clin. Invest. 95:995-1001.

12. Harding, J. W., V. L. Cook, A. V. Miller-Wing, J. M. Hanesworth, M. F. Sardinia, K. L. Hall, J. W. Stobb, G. N. Swanson, J. K. Coleman, J. W. Wright, and E. C. Harding. 1992. Identification of an AII(3-8) [AIV] binding site in guinea pig hippocampus. Brain Res. 583:340-343.

13. Miller-Wing, A. V., J. M. Hanesworth, M. F. Sardinia, K. L. Hall, J. W Wright, R. C. Speth, K. L. Grove, and J. W. Harding. 1993. Central angiotensin IV binding sites: distribution and specificity in guinea pig brain. J. Pharmacol. Exp. Ther. 266:1718-1726.

14. Chaki, S., and T. Inagami. 1992. Identification and characterization of a new binding site for angiotensin II in mouse neuroblastoma neuro-2A cells. Biochem. Biophys. Res. Commun. 182:388-394.

15. Swanson, G. N., J. M. Hanesworth, M. F. Sardinia, J. K. F. Coleman J. W. Wright, K. L. Hall, A. V. Miller-Wing, J. W. Stobb, V. I. Cook, E. C Harding, and J. W. Harding. 1992. Discovery of a distinct binding site for angiotensin II(3-8), a putative angiotensin IV. Regul. Pept. 40:409-419.

16. Jarvis, M. F., G. W. Gessner, and C. Q. Ly. 1992. The angiotensin hexapeptide 3-8 fragment potently inhibits $\left[{ }^{125} \mathrm{I}\right]$ angiotensin II binding to non-AT $\mathrm{T}_{1}$ or $-\mathrm{AT}_{2}$ recognition sites in bovine adrenal cortex. Eur. J. Pharmacol. 219:319322.

17. Sardinia, M. F., J. M. Hanesworth, F. Krishnan, and J. W. Harding. 1994 $\mathrm{AT}_{4}$ receptor structure-binding relationship: $N$-terminal-modified angiotensin IV analogues. Peptides. 15:1399-1406.

18. Booyse, F. M., B. J. Sedlock, and M. E. Rafelson. 1975. Culture of arterial endothelial cells. Thromb. Diath. Haemorrh. 34:825-839.

19. Chomczynski, P., and N. Sacchi. 1987. Single-step method of RNA isolation by acid guanidium thiocyanate-phenol-chloroform extraction. Anal. Biochem. 162:156-159.

20. Rich, D. H., B. J. Moon, and S. Harbeson. 1984. Inhibition of aminopeptidases by amastatin and bestatin derivatives. Effect of inhibitor structure on slowbinding processes. J. Med. Chem. 27:417-422. 
21. Haberl, R. L., P. J. Decker, and K. M. Einhaupl. 1991. Angiotensin degradation products mediate endothelium-dependent dilation of rabbit brain arterioles. Circ. Res. 68:1621-1627.

22. Hall, K. L., J. M. Hanesworth, A. E. Ball, G. P. Felgenhauer, H. L. Hosick, and J. W. Harding. 1993. Identification and characterization of a novel angiotensin binding site in cultured vascular smooth muscle cells that is specific for the hexapeptide (3-8) fragment of angiotensin II, angiotensin IV. Regul. Pept. 44:225-232.

23. Hanesworth, J. M., M. F. Sardinia, L. T. Krebs, K. L. Hall, and J. W. Harding. 1993. Elucidation of a specific binding site for angiotensin II(3-8) angiotensin IV, in mammalian heart membranes. J. Pharmacol. Exp. Ther. 266:1036-1042.

24. Brazsko, J. J., G. Kupryszewski, B. Witczuk, and K. Wisniewski. 1988 Angiotensin II- (3-8)-hexapeptide affects motor activity, performance of passive avoidance and a conditioned avoidance response in rats. Neuroscience. 27:777783.

25. Ahmad, S., and P. E. Ward. 1990. Role of aminopeptidase activity in the regulation of the pressor activity of circulating angiotensins. J. Pharmacol. Exp. Ther. 252:643-650.

26. Pfeffer, M. A., E. Braunwald, L. A. Moye, L. Basta, E. J. Brown, T. E. Cuddy, B. R. Davis, E. M. Geltman, S. Goldman, G. G. Flaker, et al. 1992. Effect of captopril on mortality and morbidity in patients with left ventricular dysfunction after myocardial infarction: results of the survival and ventricular enlargement trial. N. Engl. J. Med. 327:669-677.

27. Yusuf, S., C. J. Pepine, C. Garces, H. Pouleur, D. Salem, J. Kostis, C. Bened, M. Bourassa, and B. Pitt. 1992. Effect of enalapril on myocardial infarction and unstable angina in patients with low ejection fractions. Lancet. 340:11731178.

28. Rutherford, J. D., M. A. Pfeffer, L. A. Moye, B. R. Davis, G. C. Flaker P. R. Kowey, G. A. Lamas, H. S. Miller, M. Packer, J. L. Rouleau, and E. Braunwald. 1994. Effects of captopril on ischemic events after myocardial infarction: results of the survival and ventricular enlargement trial. Circulation 90:1731-1738.

29. Hamsten, A., G. Walldins, A. Szamosi, M. Blomback, U. deFaire, G Dahlen, C. Landou, and B. Wiman. 1987. Plasminogen activator inhibitor in plasma: risk factor for recurrent myocardial infarction. Lancet. 2:3-9.

30. Goldberg, M. R., W. Tanaka, A. Barchowsky, T. E. Bradstreet, J. McCrea, M.-W. Lo, E. J. McWilliams, and T. D. Bjornsson. 1993. Effects of losartan on blood pressure, plasma renin activity, and angiotensin II in volunteers. Hyperten sion (Dallas). 21:704-713.

31. Goldberg M. R. T. E. Bradstreet, E. J. McWilliams, W. K. Tanaka, S. Lipert, T. D. Bjornsson, S. A. Waldman, B. Osborne, L. Pivadori, G. Lewis, et al. 1995. Biochemical effects of losartan, a nonpeptide angiotensin II receptor antagonist, on the renin-angiotensin-aldosterone system in hypertensive patients. Hypertension (Dallas). 25:37-46. 